\title{
ROOT DEVELOPMENT AND GROWTH OF MIXED STANDS OF Eucalyptus urograndis AND Acacia mangium UNDER DIFFERENT TYPES OF SOIL TILLAGE
}

\author{
Gerhard Valkinir Cabreira ${ }^{1}$, Eduardo Vinícius da Silva ${ }^{2}$, Marcos Gervasio Pereira ${ }^{3 *}$, Tafarel Rodrigues Paula ${ }^{4}$, \\ Wilbert Valkinir Cabreira ${ }^{5}$ \\ ${ }^{1}$ Universidade Federal Rural do Rio de Janeiro, Mestre - Programa de Pós-Graduação em Ciências Ambientais e Florestais, Seropédica, Rio \\ de Janeiro, Brasil-gerhard_vc@hotmail.com \\ ${ }^{2}$ Universidade Federal Rural do Rio de Janeiro, Departamento de Silvicultura, Seropédica, Rio de Janeiro, Brasil - eduvini@gmail.com \\ ${ }^{3 *}$ Universidade Federal Rural do Rio de Janeiro, Departamento de Solos, Seropédica, Rio de Janeiro, Brasil - \\ mgervasiopereira01@gmail.com \\ ${ }^{4}$ Universidade Federal Rural do Rio de Janeiro, Graduado em Engenharia Florestal, Seropédica, Rio de Janeiro, Brasil - \\ tafarelrp@gmail.com \\ ${ }^{5}$ Universidade Federal Rural do Rio de Janeiro, Doutorando pelo Programa de Pós-Graduação em Ciências Ambientais e Florestais, \\ Seropédica, Rio de Janeiro, Brasil - wilbertvalkinir@gmail.com
}

Received for publication: 10/06/2018 - Accepted for publication: 05/10/2020

\begin{abstract}
Resumo
Desenvolvimento radicular e crescimento de povoamentos mistos de Eucalyptus urograndis E Acacia mangium em diferentes tipos de preparo de solo. Espécies arbóreas fixadoras de nitrogênio $(\mathrm{N})$ atmosférico, propiciam inúmeros benefícios ao solo. O objetivo deste estudo, foi avaliar o efeito do manejo do solo sobre o desenvolvimento das raízes e crescimento das árvores em povoamentos mistos de Eucalyptus urograndis (Eucalyptus urophylla S. T. Blak e Eucalyptus grandis W. Hill ex Maiden) e Acacia mangium Willd. Foram estabelecidos em delineamento de blocos casualizados com parcelas subdivididas, submetidas ao cultivo mínimo e cultivo intensivo, povoamento monoespecífico de Eucalyptus urograndis (1) e Acacia mangium (2), além dessas espécies em consórcio com $50 \%$ da densidade do compartimento composto de cada espécie (3). Foram mensurados o incremento em diâmetro e altura até 49 meses após instalação do experimento e amostradas raízes finas $(<2 \mathrm{~mm}$ de diâmetro) em cinco pontos diferentes em dois conjuntos de árvores por parcela até $1,0 \mathrm{~m}$ de profundidade $(0-0,1,0,1-0,3,0,3-0,5,0,5-1,0 \mathrm{~m})$ com auxílio de sonda de aço com 0,045 $\mathrm{m}$ de diâmetro interno. Após 49 meses, as árvores de E. urograndis apresentaram maior incremento em altura e diâmetro. O tratamento 2 apresentou maior densidade de raízes finas (DRF) em todas as camadas. A implantação dos povoamentos mistos intensificou a DRF de E. urograndis na camada de 0-0,1 $\mathrm{m}$. Somente na camada 0,1-0,3 m apresentou efeito no desenvolvimento radicular onde se verificou que o cultivo intensivo aumentou a DRF no tratamento 2. Assim, povoamentos mistos podem ser excelentes alternativa para a produção florestal em áreas submetidas a processo de degradação do solo.

Palavras-chaves: consórcio, competição, leguminosa, raízes finas
\end{abstract}

\begin{abstract}
Atmospheric nitrogen $(\mathrm{N})$-fixing tree species provide numerous benefits for the soil. The objective of this study was to evaluate the effect of soil management on root development and growth of trees in mixed stands of Eucalyptus urograndis (Eucalyptus urophylla S. T. Blak and Eucalyptus grandis W. Hill ex Maiden) and Acacia mangium Willd. These species were established in a randomized block design with split plots, subjected to minimum tillage and intensive tillage, monospecific stand of Eucalyptus urograndis (1) and Acacia mangium (2), in addition to the intercropping of these species with $50 \%$ of the density of the compound compartment of each species (3). Increments in diameter and height were measured up to 49 months after installation of the experiment and fine roots $(<2 \mathrm{~mm}$ in diameter) were sampled at five different points in two sets of trees per plot up to $1.0 \mathrm{~m}$ depth $(0-0.1,0.1-0.3,0.3-0.5,0.5-1.0 \mathrm{~m})$ using a steel probe with $0.045 \mathrm{~m}$ internal diameter. After 49 months, E. urograndis trees showed greater increments in height and diameter. Treatment 2 showed a higher fine root density (FRD) in all layers. The implementation of mixed stands intensified the FRD of E. urograndis in the 0-0.1 m layer. Effect on root development was observed only in the 0.1-0.3 m layer, where intensive tillage increased FRD in treatment 2 . Thus, mixed stands can be an excellent alternative for forest production in areas subjected to soil degradation.

Keywords: intercropping, competition, legume, fine roots
\end{abstract}

\section{INTRODUCTION}

Species of the genus Eucalyptus are the most planted in Brazil, corresponding in 2018 to $72.8 \%$ (5.7 million hectares) of the area occupied by forest plantations (IBÁ, 2019). Characteristics such as fast growth, high productivity and adaptability to variable soil and climate conditions explain such a high 
proportion of total cultivation in planted forests in Brazil (COSTA et al., 2016).

The fact that eucalyptus is cultivated predominantly in a monospecific system, in extensive areas of soils with low natural fertility, stimulates the challenge of developing new planting and management arrangements that promote improvements in soil quality, productivity of the sector and its potential to receive new investments (SANTOS et al., 2010). Nitrogen (N) availability is often a limiting factor for eucalyptus growth, which makes it necessary to search for methods that provide additional $\mathrm{N}$ contribution, ensuring high and sustainable production of the stand (LACLAU et al., 2010). In this context, mixed stands with atmospheric $\mathrm{N}$-fixing tree legumes can provide better nutrient cycling and promote improvements in the quality of soil carbon stocks (KOUTIKA et al., 2014; SANTOS et al., 2016).

Complementation of niches to obtain light, water and nutrients has been determinant for mixed stands of Eucalyptus and Acacia mangium to achieve greater biomass accumulation than monoculture plantations (BOUILLET et al., 2013; SANTOS et al., 2016). According to Forrester (2014), interactions of facilitation and competitive reduction among tree species are more evident in sites with low initial availability of nutrients, provided that the interactions between the species contribute to an increase in the availability, acquisition and efficiency of the use of these resources. From this information, it is of great importance to choose the species, especially planning how they will be distributed in the field, in order to reduce competition and favor the facilitation between species (BOUILLET et al., 2013; SANTOS et al., 2016). Thus, it is also important to know the characteristics of the distribution of aerial growth and to evaluate the root interaction between species, since it is through the root system that water, and nutrients are absorbed.

Fine roots play a key role in capturing and transporting water and the nutrients needed for plant growth (FORT et al., 2017). However, there are few studies on production and growth patterns and their response to the availability of soil resources, especially for tropical forests (LIMA et al., 2010). In this context, the objective of this study was to evaluate the effect of soil management on root development and growth of trees in mixed stands of Eucalyptus urograndis (Eucalyptus urophylla S. T. Blak and Eucalyptus grandis W. Hill ex Maiden) and Acacia mangium Willd. Thus, our hypotheses are that (1) A. mangium benefits E. urograndis in the intercropping in relation to its growth, when there is better exploration by its root system, and (2) that in areas of intensive tillage, the intercropping between the two species promotes better results than those obtained with minimum tillage.

\section{MATERIAL AND METHODS}

\section{Study area and experimental design}

The experiment was conducted in the Experimental field of Embrapa Agrobiology (22 $44^{\prime} 25^{\prime \prime S}$ and $\left.43^{\circ} 40^{\prime} 16^{\prime \prime} \mathrm{W}\right)$, in the municipality of Seropédica-RJ, Brazil, in an area that had been fallow for more than 15 years. According to Köppen's classification, the climate is Aw, characterized by rainy summers and dry winters, with average rainfall of $1,275 \mathrm{~mm}$, average monthly temperature of $23.7^{\circ} \mathrm{C}$ and average annual relative humidity of $69.3 \%$ (ALONSO et al., 2015).

The relief is predominantly gently undulating ( $<5 \%$ of slope), and the soil is classified as Planossolo Háplico (Albaqualf) according to the Brazilian Soil Classification System (EMBRAPA, 2018), characterized by the presence of sandy surface horizon and planic B subsurface horizon, with clayey texture with influence of the water table at lower points of the toposequence. Table 1 shows the characterization of soil fertility and texture in the area at the time of installation of the experiment (2009).

Tabela 1. Caracterização da fertilidade e textura do solo nas camadas de 0-0,1 e 0,1-0,2 m, coletadas na área experimental em 2009.

Table 1. Soil fertility and texture characterization in the layers of $0-0.1$ and $0.1-0.2 \mathrm{~m}$, sampled in the experimental area in 2009.

\begin{tabular}{llllllllllll}
\hline Layer & $\mathrm{pH}$ & $\mathrm{Ca}^{+2}$ & $\mathrm{Mg}^{+2}$ & $\mathrm{Al}^{+3}$ & $\mathrm{H}+\mathrm{Al}$ & $\mathrm{K}$ & $\mathrm{P}$ & $\mathrm{OC}$ & Sand & Silt & Clay \\
\hline $\mathrm{m}$ & $\mathrm{H}_{2} 0$ & $----------\mathrm{cmol}_{\mathrm{c}} \mathrm{dm}^{3}---------$ & & $\mathrm{mg} \mathrm{dm}^{-3}$ & $----------\mathrm{g} \mathrm{kg}^{-1}-----------$ & \\
\hline $0-0.1$ & 4.87 & 0.46 & 0.69 & 0.13 & 2.47 & 35 & 0.28 & 3.64 & 865 & 72 & 63 \\
$0.1-0.2$ & 4.95 & 0.26 & 0.60 & 0.22 & 2.59 & 27 & 0.37 & 2.71 & 859 & 74 & 67 \\
\hline
\end{tabular}

$\mathrm{pH}$ in $\mathrm{H}_{2} \mathrm{O} ; \mathrm{Ca}^{+2}, \mathrm{Mg}^{+2}$, $\mathrm{Al}^{+3}$ : extracted with $1 \mathrm{~mol} \mathrm{~L}^{-1} \mathrm{KCl} ; \mathrm{H}+\mathrm{Al}$ : extracted with $\mathrm{C}_{4} \mathrm{H}_{6} \mathrm{O}_{4} \mathrm{Ca}$ at $\mathrm{pH} 7 ; \mathrm{K}$ and P: extracted with Mehlich 1. OC: organic carbon. Values represent the mean levels obtained from four samples in each layer, representing the area covered by the experimental plots. Source: Santos et al. (2016).

Three treatments of E. urograndis and A. mangium (Table 2) were subjected to two different managements, called minimum tillage and intensive tillage. For this, the study consisted of four randomized 
blocks (36 x $105 \mathrm{~m})$ in two split plots (18 x $105 \mathrm{~m})$. In the minimum tillage, subsoiling was performed in the planting rows and the area was tilled up to $0.3 \mathrm{~m}$ deep. In the intensive tillage, 12 successive passes of a plow, followed by a plowing harrow, were performed with intervals of 3 to 4 days, until about 20 days before planting the seedlings.

Table 2. Composition, density of Eucalyptus urograndis (E) and Acacia mangium (A) trees and spacing used in the treatments allocated to the subplots of the different types of soil management.

Tabela 2. Composição, densidade de árvores de Eucalyptus urograndis (E) e Acacia mangium (A) e espaçamentos usados nos tratamentos alocados nas subparcelas dos diferentes tipos de manejo do solo.

\begin{tabular}{ccccc}
\hline $\mathrm{N}^{\mathrm{O}}$ & Treatment & Composition & Density & Spacing (m) \\
\hline 1 & $0 \mathrm{~A}: 100 \mathrm{E}$ & Monospecific of Eucalyptus urograndis & $100 \% \mathrm{E}$ & $3 \times 3$ \\
2 & $100 \mathrm{~A}: 0 \mathrm{E}$ & Monospecific of Acacia mangium & $100 \% \mathrm{~A}$ & $3 \times 3$ \\
3 & $50 \mathrm{~A}: 50 \mathrm{E}$ & Acacia mangium $\mathrm{x}$ Eucalyptus urograndis & $50 \% \mathrm{~A}+50 \% \mathrm{E}$ & $3 \times 3$ \\
\hline
\end{tabular}

The subplots had 42 trees in total (density of 1111 trees $\mathrm{ha}^{-1}$ ). In treatment 3 , the planting of $E$. urograndis and A. mangium was alternated. To avoid the edge effect (Figure 2) and the possible influence of neighboring plots, an area corresponding to the 16 central plants was established as the usable plot, disregarding two rows of plants along the perimeter of each plot.

\section{Determination of height, diameter and fine roots}

The increment in tree height was determined on five occasions $(8,12,21,30$ and 49 months after the experiment was installed, using the vertex hypsometer. Diameter at breast height (DBH) was measured from the 21 st month after installation $(\mathrm{DBH}>0.2 \mathrm{~m})$, using a diameter tape.

To determine the distribution of live fine roots $(<2 \mathrm{~mm}$ diameter $)$ in the soil profile, evaluations were performed in each plot at five points between four trees, in four layers up to $1 \mathrm{~m}$ deep $(0-0.1,0.1-0.3,0.3-0.5$, $0.5-1.0 \mathrm{~m}$ ) using a steel probe with $0.045 \mathrm{~m}$ internal diameter and $1 \mathrm{~m}$ length, with a volume of approximately $1.6 \mathrm{dm}^{3}$.

The soil samples were sent to the laboratory and washed in running water on a 0.5 -mm-mesh sieve to remove soil. All the organic material found was stored in bottles containing $70 \%$ alcohol solution for fixation and subsequent separation of live roots (JOHANSEN, 1940). After washing and storing the samples, only the live fine roots of $A$. mangium and E. urograndis were separated using tweezers and a white tray. Dead roots (brittle and with opaque color) and other impurities were discarded during separation.

The separation of the dead and living roots of A. mangium and E. urograndis was performed visually, considering morphological characteristics, color, flexibility and amount of bifurcations. According to Silva et al. (2009), eucalyptus roots have a greater amount of bifurcations than legume roots and a light brown color, while A. mangium roots showed light yellow color, almost translucent. To identify the roots of the different species, the roots present in the monospecific stands ( 1 and 2) were first identified in order to observe the characteristics of the roots of each species, for subsequent separation in the mixed stand (3).

After separation, the roots were dried at $60{ }^{\circ} \mathrm{C}$ until reaching constant mass and weighed on analytical scale (accuracy of $0.0001 \mathrm{~g}$ ). Fine root density (FRD) was calculated considering the mass of roots in relation to the sample volume obtained at each depth.

\section{Statistical analysis}

The data set was tested for homogeneity of variances (Bartlett's test) and normal distribution (ShapiroWilk test). After the assumptions were met, F test was carried out between the treatments in each layer. When significant differences were observed, the treatments and forms of soil management were compared by Tukey test at $5 \%$ significance level. R software was used for statistical analysis.

\section{RESULTS}

\section{Shoot growth}

Homogeneity of variances and normal distribution of data were observed. For height, under intensive tillage (Figure 1B), a significant difference can be observed from 30 days on, when E. urograndis trees regardless of the treatment had higher values than A. mangium trees. However, in the mixed stand (3), E. urograndis trees showed higher growth compared to the monospecific stand (1). For minimum tillage 
(Figure 1A), a significant difference can be observed only at 49 months, when E. urograndis trees in treatments 1 and 3 showed similar growth, but with values higher than those of $A$. mangium trees.
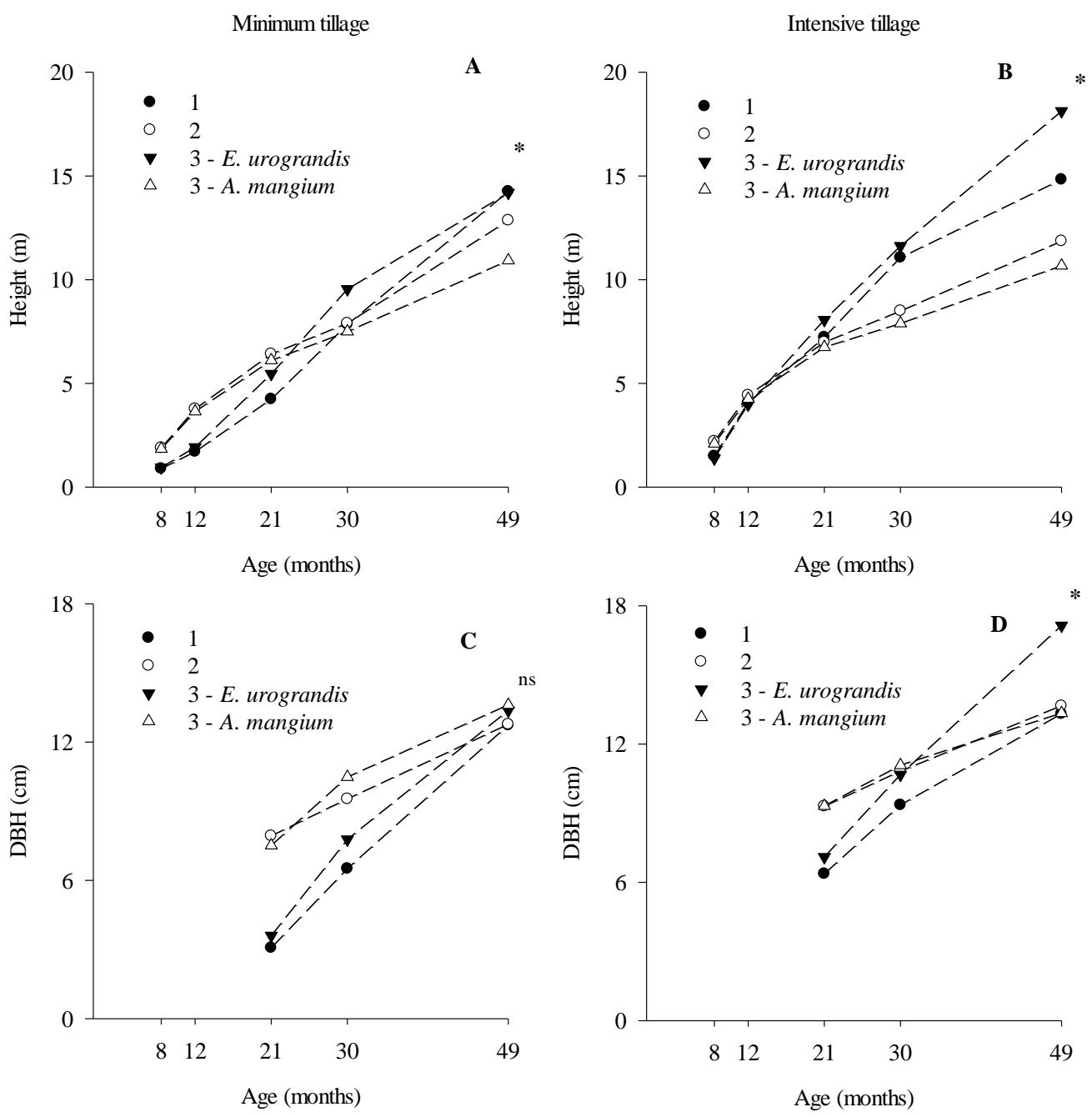

Figure 1. Shoot growth; with height represented by A and B and diameter at breast height (DBH) represented by $\mathrm{C}$ and D; of trees in different treatments. 1 and 2 for pure stands of Eucalyptus urograndis and Acacia mangium, respectively, and 3 for mixed stands; for 8, 12, 21, 30 and 49 months of age. * represents significant difference $(\mathrm{p}<0.05)$ and ${ }^{\mathrm{ns}}$ represents absence of significant difference $(\mathrm{p}<0.05)$.

Figura 1. Crescimento da parte aérea; sendo a altura representada por A e B e diâmetro altura do peito (DAP) por $\mathrm{C}$ e D; das árvores nos diferentes tratamentos. 1 e 2 para povoamentos puros de Eucalyptus urograndis e Acacia mangium respectivamente, 3 para povoamentos mistos; para 8, 12, 21, 30 e 49 meses de idade. * representa diferença significativa $(\mathrm{p}<0,05) \mathrm{e}^{\mathrm{ns}}$ representa ausência de diferença significativa $(\mathrm{p}<0,05)$.

Regarding DBH, in the first two measurements (21 and 30 months), A. mangium trees (treatment 2 and 3) had significantly higher values. However, at the end of the experiment there was no significant difference between the species under minimum tillage. Thus, A. mangium trees grew similarly to E. urograndis trees in both pure and mixed treatments (Figure 1C). Under intensive tillage (Figure 1D), A. mangium trees showed higher values than E. urograndis trees only at 21 months. At the end of the experiment, E. urograndis trees (from treatment 3) showed a greater increment in DBH.

When comparing the different types of management, A. mangium trees showed no alterations in the height and diameter growth patterns between treatments. On the contrary, E. urograndis showed the 
greatest increment in height and diameter in the mixed stand (3) under intensive tillage.

\section{Vertical distribution of fine roots}

In the 0-0.1 m layer, there was higher FRD for both types of soil tillage (Figure 2). However, only in the 0.1-0.3 m layer there was a significant difference between the types of soil tillage, where intensive tillage showed the highest means (Figure 2A).
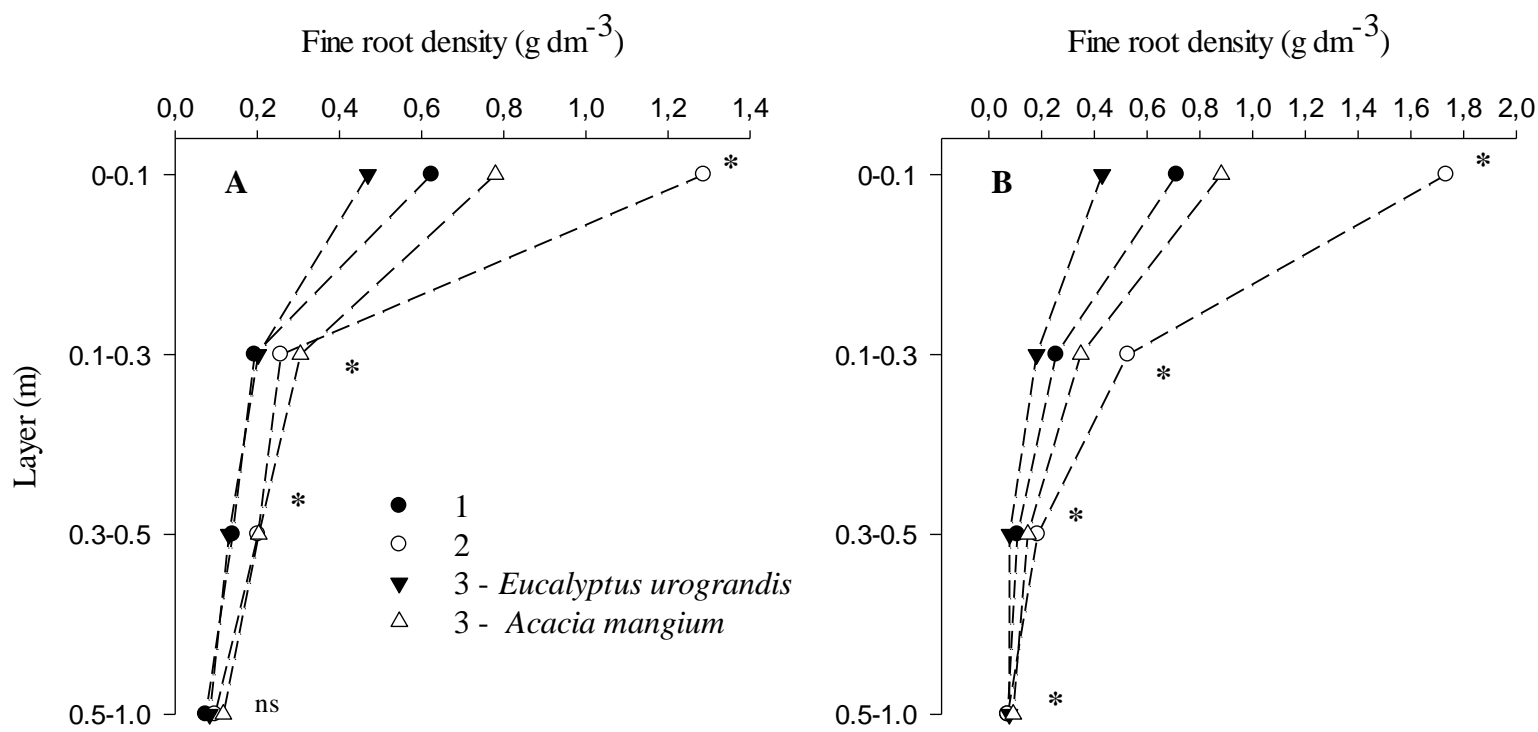

Figure 2. Fine root density in each treatment for each layer under minimum tillage (A) and intensive tillage (B). * represents significant difference $(\mathrm{p}<0.05)$ and ${ }^{\text {ns }}$ represents absence of significant difference $(\mathrm{p}$ $<0.05)$.

Figura 2. Densidade de raízes finas em cada tratamento para cada camada para cultivo mínimo (A) e intensivo (B). * representa diferença significativa $(\mathrm{p}<0,05) \mathrm{e}^{\mathrm{ns}}$ representa ausência de diferença significativa $(\mathrm{p}<0,05)$.

As a function of the treatments, only in the 0.5-1.0 m layer there was no significant difference for the types of management. For the other depths, the monospecific stands of A. mangium (2) had the highest results (Figure 2), while the lowest values of FRD were verified in E. urograndis plants in both pure (1) and mixed (3) stands in all layers evaluated.

By comparing the effects of the type of treatment performed on each species, it was possible to observe that, for A. mangium, the values were higher in the $0-0.1 \mathrm{~m}$ layer. In the mixed stand, the values of density remained higher in the $0-0.1 \mathrm{~m}$ layer, but there was an increase in root density in deeper layers, especially in the 0.2-0.5 m layer under minimum tillage. For E. urograndis in the mixed stand, root density was intensified in the 0-0.1 m layer, which can be justified by the presence of $A$. mangium in the system.

When analyzing the effect of management on the treatment in the 0.1-0.5 m layer, to evaluate the occurrence of a statistically significant difference at this depth, it was possible to observe higher FRD for $A$. mangium in monospecific treatments under intensive tillage (Figure 3). 


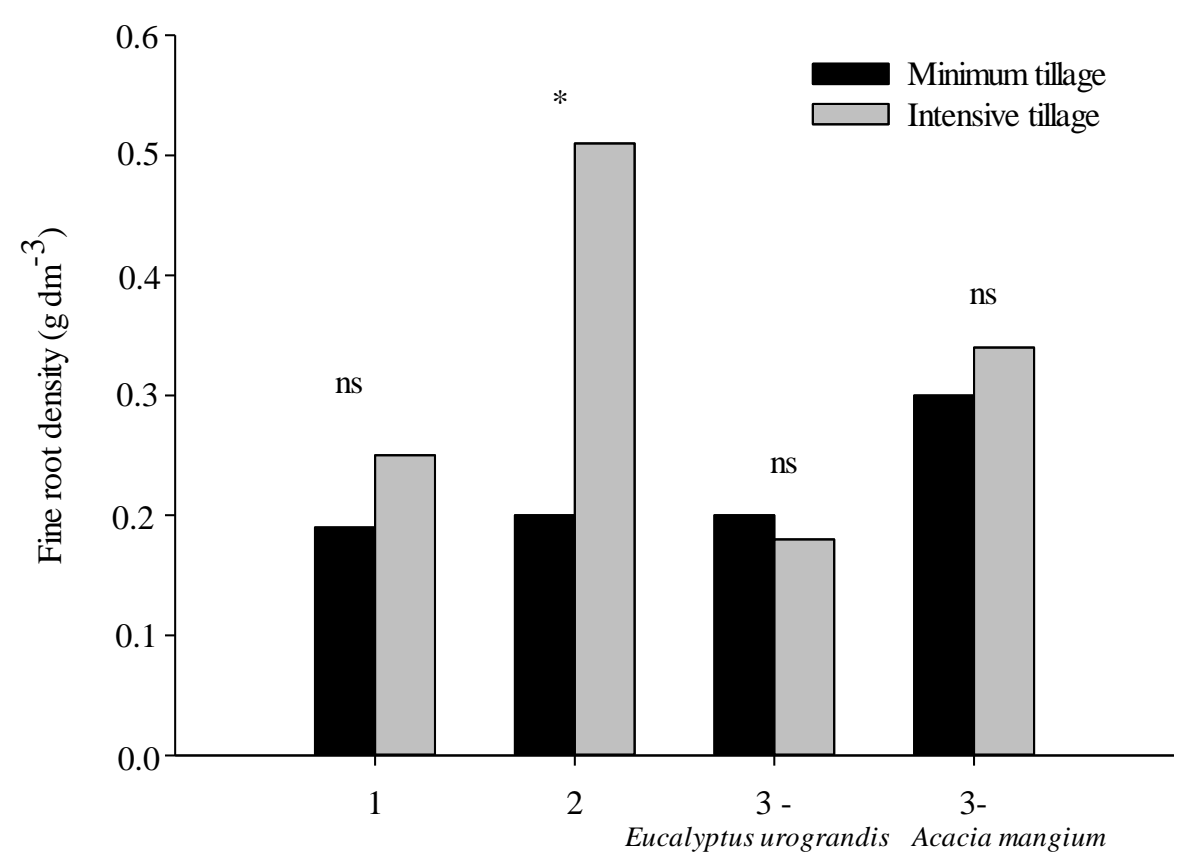

Figure 3. Fine root density in each treatment for the $0.1-0.3 \mathrm{~m}$ layer comparing the minimum tillage and intensive tillage. $*$ represents significant difference $(\mathrm{p}<0.05)$ and ${ }^{\mathrm{ns}}$ represents absence of significant difference $(\mathrm{p}<0.05)$.

Figura 3. Densidade de raízes finas em cada tratamento para a camada de 0,1-0,3 m comparando os cultivos mínimo e intensivo. * representa diferença significativa $(\mathrm{p}<0,05)$ e ${ }^{\mathrm{ns}}$ representa ausência de diferença significativa $(\mathrm{p}<0,05)$.

\section{DISCUSSION}

\section{Shoot growth}

In the initial phase of planting of the stands, the low $\mathrm{N}$ supply due to the soil class (Planossolo Albaqualf) of the site and low litter supply limited the growth of E. urograndis in both height and DBH. Santos et al. (2017) demonstrated that, in sandy soil and under mixed stands, litter decomposition is accelerated due to the synergy that its residues add to the process. After 49 months, litter mineralization processes and direct transfer from E. urograndis roots to Acacia mangium allowed significant amounts of biologically fixed $\mathrm{N}$ to become available to eucalyptus (PAULA et al., 2015). In addition, the progressive increment in the DBH of $E$. urograndis in treatment 3 may have occurred due to the spacing between $E$. urograndis trees, which may have facilitated the acquisition of resources (i.e., water, light and nutrients) (SANTOS et al., 2016). In studies conducted by Coelho et al. (2007), results similar to those of this study were found. However, Silva et al. (2009) found higher values of height of A. mangium when compared to E. grandis since the first months after planting. This pattern can be justified by its adaptation to local edaphoclimatic characteristics with rainy summers and high temperatures; for being an aggressive and competitive species in growth, after finding better development conditions, Acacia mangium was able to grow together with Eucalyptus urograndis. Bouillet et al. (2008) explain that the greater fixation of $\mathrm{N}$ by the legumes occurs in the initial phase of growth in mixed stands, which also justifies its rapid growth.

Regarding soil tillage, Jorge et al. (2012) stated that it is the activity that most influences the physical behavior of the soil, because it acts directly on its structure, porosity and density. This statement may justify the results obtained in the present study, since the successive operations of plowing and harrowing in the intensive tillage may have increased soil porosity, favoring water infiltration, also enabling a better development of roots.

In a study carried out by Vieira et al. (2011), the growth in diameter of E. urograndis and Acacia mearnsii, both at six and 18 months of age, did not differ significantly between treatments. Silva et al. (2009) verified that the basal area of A. mangium in the monospecific stand was similar to that of E. grandis also in monospecific stand at 12 months after planting. Santos et al. (2016) highlighted that the intercropped $E$. 
urograndis was favored by the greater supply of $\mathrm{N}$ from A. mangium.

The success of many mixed stands has been attributed in part to the complementarity of niches to obtain light, water and nutrients (BOUILLET et al., 2013; SANTOS et al., 2016). With better growth conditions for both species, the possibility of positive interactions is higher, partly due to the better conditions for $\mathrm{N}$ fixation (COELHO et al., 2007). For Vezzani et al. (2001), the growth response may also be a consequence of other factors that interact in the treatment with intercropping, which reduce competition and/or facilitate development. One of the factors that may have contributed to this growth response is the conformation of the treetops. A. mangium probably allowed better exploration of space by E. urograndis, favoring the production of leaves and branches. With a larger photosynthetic area, there is better utilization of solar radiation by E. urograndis in intercropping.

In the initial phase, there is higher interspecific competition and, after this phase, intraspecific competition prevails, becoming more severe when the planting spacing is denser or under greater scarcity of growth factors (COELHO et al., 2007). Vezzani et al. (2001) also observed that the amount of wood in cubic meters, obtained in the intercropping, was identical to that of pure Eucalyptus stands. With this, it is possible to note the great potential of implementing intercropped stands in areas that have undergone an intense exploitation process.

It is observed that in treatment 3, due to intra- and interspecific competition, the growth of the species was lower than that obtained in the monospecific treatment. This result has also been observed by Coelho et al. (2007) and Silva et al. (2009) in different experiments with E. grandis and A. mangium.

\section{Vertical distribution of fine roots}

The highest values of FRD in the 0-0.1 m layer confirmed data reported in the literature. In general, the biomass of fine roots decreases exponentially from the surface to the deepest layers of the soil in different forest biomes, mainly due to the greater availability of water and nutrients in the surface layers of the soil profile (FINÉR et al., 2011). This pattern explains the higher intensity of fine roots up to $30 \mathrm{~cm}$ deep (BAUHUS et al., 2000; COELHO et al., 2007) and the importance of trees in concentrating the growth of fine roots in the surface layer, due to their greater effectiveness and efficiency in nutrient acquisition. At greater depths, the values tended to decrease until they were no longer significant.

In the 0.1-0.3 m layer, intensive tillage led to better results. The same pattern was observed by Coelho et al. (2007) in studies that considered the density of fine roots of E. grandis. These authors verified that the variations only occurred in the 0.1-0.3 m layer in the different treatments. In this layer of soil, Bauhus et al. (2000) found more than $80 \%$ of the total length of roots analyzed. In the $0.5-1.0 \mathrm{~m}$ layer, the means of the treatments were considered similar, due to the tendency of the root density in the deeper layers to become progressively lower. Silva et al. (2009) in a similar experiment located in the municipality of Itatinga, São Paulo, on a hillside top, with soil classified as medium-textured Latossolo Vermelho-Amarelo Distrófico (Oxisol), verified the same situation in which the difference between the FRD of A. mangium was significant when compared to that of $E$. grandis in the surface layer of the soil.

The different growth rates of the stands and the root density obtained in the layers of 0-0.1, 0.1-0.3 and 0.3-0.5 m can be attributed to the great activity of fine roots due to the greater availability of soil nutrients and to the biogeochemical cycling processes through the deposition and mineralization of litter in the surface layers, which are richer in organic matter (GONÇALVES; CARLYLE, 1994). Therefore, this pattern indicates that the difference of treatments in these three layers can be justified by the greater intra- and interspecific competition for better development conditions. According to Vezzani et al. (2001), in mixed stands, from the initial phase to the formation of the canopy, there is a competition for resources (water, light and nutrients) between the legume and the species in question.

Regarding the means of FRD for each treatment in each layer, Silva et al. (2009) observed different results. These authors verified that A. mangium in the monospecific treatment showed lower values of FRD until 18 months after planting, characterizing slow root growth. This pattern shows the low ability of A. magnum to compete for water and nutrients with E. grandis at that site. Data presented by Coelho et al. (2007), obtained in the same experimental station, also showed lower growth of the aerial part and root system of A. mangium compared to E. grandis. Part of this lower relative development of A. mangium compared to E. grandis was attributed by the authors to the dry and cold period that occurs between May and September at that location.

As the soil of the site had low fertility, A. mangium needed to produce higher FRD aiming at greater nutrient uptake. However, the local climatic factors with high temperatures and precipitation in the summer enabled better development, so root density was intensified. In addition, due to the extremely sandy texture, and thus low capacity to retain water and bases, there was greater losses of nutrients, causing the species to deepen its roots and increase their production. 
When mixed planting was introduced, the values of FRD remained higher in the 0-0.1 m layer, but there was an increase in the values in the deeper layers, especially at 0.3-0.5 m under minimum tillage, which is considered by Silva et al. (2009) a consequence of the competition and dominance of E. urograndis, causing A. mangium to distribute its fine roots to greater depths. According to Vezzani et al. (2001), there is greater accumulation of nutrients in the surface layers, resulting from the deposition of plant material with higher content of available nitrogen.

Studying the nutritional aspects of pure and mixed stands of Eucalyptus saligna and Acacia mearnsii, Vezzani et al. (2001) highlighted that treatments with the presence of A. mearnsii had higher organic matter content, both in surface and in the deepest layers of the soil. Such increase in organic matter is mainly due to the greater addition of residues and/or the higher speed of litter decomposition due to its lower carbon/nitrogen $(\mathrm{C} / \mathrm{N})$ ratio. As a consequence, there is greater exposure of the soil, because of the intensive activities, causing nutrients to become available faster due to the increase in mineralization rates, which resulted in this development of $A$. mearnsii. Also in their studies, these authors verified that the residues containing A. mearnsii released greater amounts of nitrogen; in addition, the plant material of the treatment with E. urograndis in monoculture had a much higher $\mathrm{C} / \mathrm{N}$ ratio than the litter composition of the mixed treatment, making the decomposition the residues difficult. The lower $\mathrm{C} / \mathrm{N}$ ratio favors a faster decomposition of organic material compared to the treatment with pure eucalyptus. This favors greater loss of carbon and release of nutrients. Consequently, there is a greater accumulation of nutrients in comparison to E. urograndis in monoculture, in the first centimeters of the soil, increasing the availability of nutrients where fine roots are located. Together with this, the greater number of plowing and harrowing operations intensified the mineralization of litter, since the soil was more exposed to climatic conditions that favor the decomposition process.

\section{CONCLUSIONS}

- Introduction of A. mangium favored the growth in height and diameter of E. urograndis, and the stratification of the root system of both species with mixed stand indicates that they can occupy different niches of root exploration in the soil horizons, thus evidencing success for this intercropping.

- The use of mixed stands of E. urograndis with legume forest species can be an excellent alternative for forest production in areas subjected to intense degradation process (intensive tillage).

\section{REFERENCES}

ALONSO, J. K.; LELES, P. S. S.; FERREIRA, L. N.; OLIVEIRA, N. S. A. Aporte de serapilheira em plantio de recomposição florestal em diferentes espaçamentos. Ciência Florestal, v. 25, p. 1-11, 2015.

BAUHUS, J.; KHANNA, P. K.; MENDEN, N. Aboveground and belowground interactions in mixed plantations of Eucalyptus globules and Acacia mearnsii. Canadian Journal of Forest Research, Ottawa, v. 30, n. 12, p. 1886-1894, 2000.

BOUILlet, J. P.; LAClAU, J. P.; GONÇAlVES, J. L. M.; MOREIRA, M. Z.; TRIVELIN, P. C. O.; JOURDAN, C.; SILVA, E. V.; PICCOLO, M. C.; TSAI, S. M.; GALIANA, A.. Mixed-species plantations of Acacia mangium and Eucalyptus grandis in Brazil: Nitrogen accumulation in the stands and biological $\mathrm{N}_{2}$ fixation. Forest Ecology and Management, Amsterdam, v. 255, p. 3918-3930, 2008.

BOUILlET, J. P.; LACLAU, J. P.; GONCALVES, J. L. M.; VOIGTLAENDER, M.; GAVA, J. L.; LEITE, F. P.; HAKAMADA, R.; MARESCHAL, L.; MABIALA, A.; TARDY, F.; LEVILLAIN, J.; DELEPORTE, P.; EPRON, D.; NOUVELLON, Y. Eucalyptus and Acacia tree growth over entire rotation in single-and mixedspecies plantations across five sites in Brazil and Congo. Forest Ecology and Management, Amsterdam, v. 301, p. 89-101, 2013.

COELHO, S. R. F.; GONÇALVES, J. L. M.; MELLO, S. L. M.; MOREIRA, R. M.; SILVA, E. V.; LACLAU, J. P. Crescimento, nutrição e fixação biológica de nitrogênio em plantios mistos de eucalipto e leguminosas arbóreas. Pesquisa Agropecuária Brasileira, Brasília, v. 42, p. 759-768, 2007.

COSTA, M. G.; GAMA-RODRIGUES, A. C.; GONÇALVES, J. L. M.; GAMA-RODRIGUES, E. F.; SALES, M. V.; ALEIXO, S. Labile and non-labile fractions of phosphorus and Its transformations in soil under Eucalyptus Plantations, Brazil. Forests, v.7, 2016.

EMPRESA BRASILEIRA DE PESQUISA AGROPECUÁRIA (EMBRAPA). Sistema Brasileira de Classificação de Solos. 5a edição, Brasília, 2018. 356 p. 
FINÉR, L.; OHASHI, M.; NOGUCHI, K.; HIRANO, Y. Factors causing variation in fine root biomass in forest ecosystems. Forest Ecology and Management, Amsterdam, v. 261, p. 265-277, 2011.

FORRESTER, D. I. The spatial and temporal dynamics of species interactions in mixed-species forests: from pattern to process. Forest Ecololy Management, Amsterdam, v. 312, p. 282- 292, 2014.

FORT, F.; VOLAIRE, F.; GUILIONI, L.; BARKAOUI, K.; NAVAS, M. L.; ROUMET, C. Root traits are related to plant water use among rangeland Mediterranean species. Functional Ecology, v. 31, p. 1700-1709, 2017.

GONÇALVES, J. L. M.; CARLYLE, J. C. Modelling the influence of moisture and temperature on net nitrogen mineralization in a forested sandy soil. Soil Biology \& Biochemistry, Lisboa, v. 26, p. 1557-1564, 1994.

INDÚSTRIA BRASILEIRA DE ÁRVORES. Relatório anual IBÁ 2019. Brasília, 2019.

JOHANSEN, D. A. Plant micro-technique. New Yok: McGraw-Hill Book, 1940. 523 p.

JORGE, R. F.; ALMEIDA, C. X. de.; BORGES, E. N.; PASSOS, R. R. Distribuição de poros e densidade de latossolos submetidos a diferentes sistemas de uso e manejo. Bioscience Journal, Uberlândia, v. 28, p. 159-169, 2012.

KOUTIKA, L. S.; EPRON, D.; BOUILLET, J.P.; MARESCHAL, L. Changes in N and C concentrations, soil acidity and $\mathrm{P}$ availability in tropical mixed acacia and eucalypt plantations on a nutrient-poor Sandy soil. Plant and Soil, v. 379, p. 205-216, 2014.

LACLAU, J. P.; RANGER, J.; GONÇALVES, J. L. M.; MAQUÈRE, V.; KRUSCHE, A. V.; M'BOU, A. T.; NOVELLON, Y.; SAINT-ANDRÉ, L.; BOUILLET, J. P.; PICCOLO, M. C.; DELEPORTE, P. Biogeochemical cycles of nutrients in tropical Eucalyptus plantations. main features shown by intensive monitoring in Congo and Brazil. Forest Ecoology Management, v. 259, p. 1771-1785, 2010.

LIMA, T. T. S.; MIRANDA, I. S.; VASCONCELOS, S. S. Effects of water and nutrient availability on fine root growth in eastern Amazonian forest regrowth, Brazil. New Phytologist, v. 187, p. 622-630, 2010.

PAUlA, R. R.; BOUILlET, J.P.; GONÇALVES, J. L.; TRIVELIN, P. C. O.; BALIEIRO, F. C.; NOUVELLON, J. C.; JÚNIOR, J. C.; BORDON, B.; LACLAU, J.P. Nitrogen fixation rate of Acacia mangium Wild at mid rotation in Brazil is higher in mixed plantations with Eucalyptus grandis Hill ex Maiden than in monocultures. Annals of Forest Science, v. 75, p. 1-14, 2018.

SANTOS, M. F.; BALIEIRO, F. C.; ATAÍDE, D. H. S.; DINIZ, A.R.; CHAER, G.M. Dynamics of aboveground biomass accumulation in monospecific and mixed-species plantations of Eucalyptus and Acacia on a Brazilian sandy soil. Forest Ecology and Management, 363, p. 86-97, 2016

SANTOS, A. B. dos.; SANTOS, F. M.; SILVA, R. B. da.; BALIEIRO, F. C.; CHAER, G. M. Biomassa e atividade microbiana do solo em plantios puros e mistos de eucalipto e Acacia mangiun submetidos ao preparo mínimo e intensivo do solo. Boletim de Pesquisa e desenvolvimento, 2010, 18p.

SANTOS, F. M.; BALIEIRO, F. C.; ATAÍDE, D. H. dos. S.; DINIZ, A. R.; CHAER, G. M. Dynamics of aboveground biomass accumulation in monospecific and mixed-species plantations of Eucalyptus and Acacia on a Brazilian Sandy soil. Forest Ecology and Management, v. 363, p. 86-97, 2016.

SANTOS M. F.; CHAER G. M.; DINIZ, A. R.; BALIEIRO, F. C. Nutrient cycling over five years of mixedspecies plantations of Eucalyptus and Acacia on a sandy tropical soil. Forest Ecololy Management, v. 384, p. $110-121,2017$.

SILVA, E. V.; GONCALVES, J. L. M.; COELHO, S. R. F.; MOREIRA, R. M.; JOURDAN, C.; LACLAU, J. P. Dynamics of fine root distribution after establishment of monospecific and mixed-species plantations of Eucalyptus grandis and Acacia mangium. Plant and Soil, v. 325, p. 305-318, 2009.

VEZZANI, F. M.; TEDESCO, M. J.; BARROS, N. F. Alterações dos nutrientes no solo e nas plantas em consórcio de eucalipto e Acácia negra. Revista Brasileira de Ciência do Solo, Viçosa, v. 25, p. 225-231, 2001.

VIERA, M.; SCHUMACHER, M.V.; LIBERALESSO, E. Crescimento e produtividade de povoamentos monoespecíficos e mistos de eucalipto e acácia-negra. Pesquisa Agropecuária Tropical, Brasília, v. 41, p. 415421, 2011. 